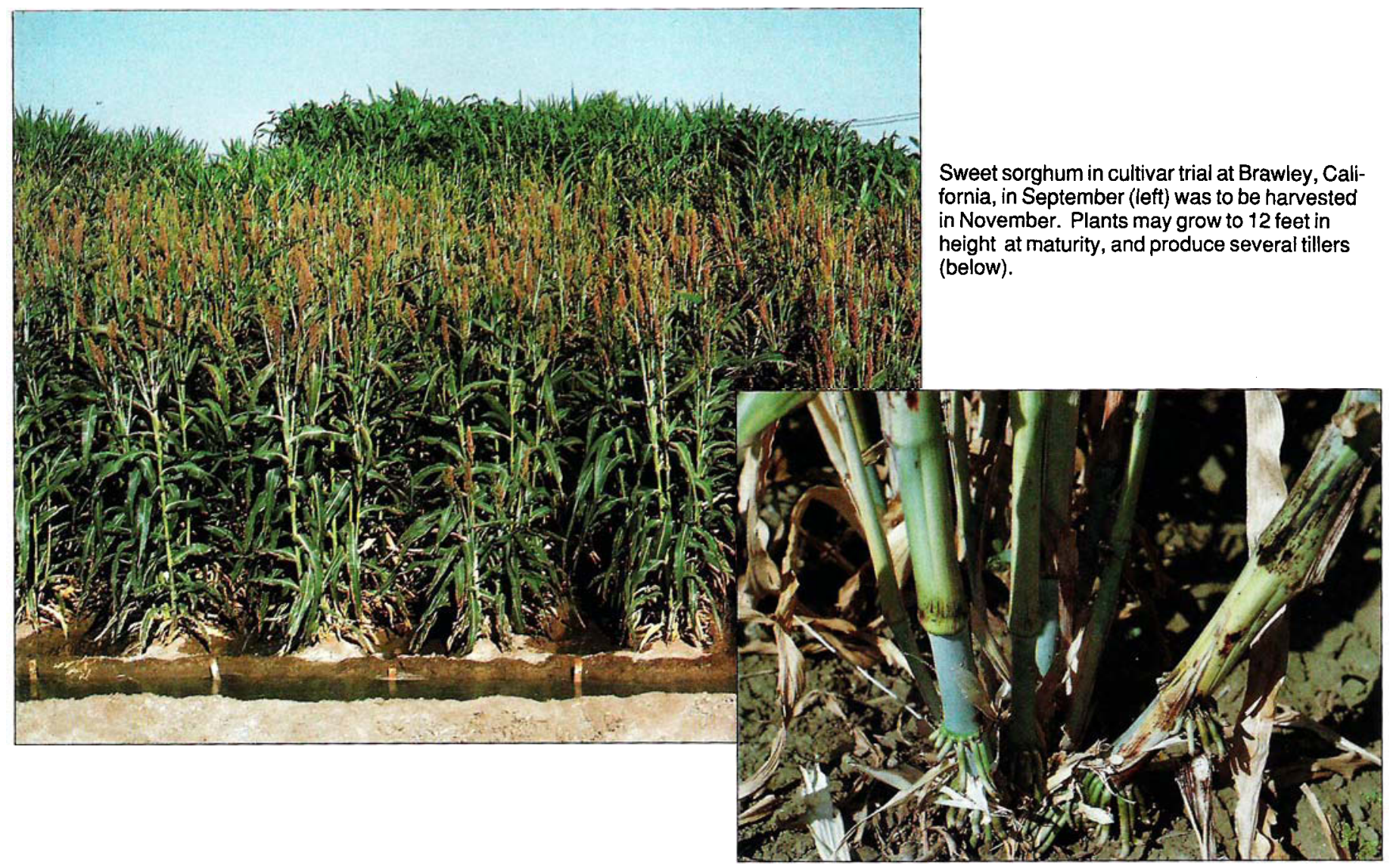

\title{
Sweet sorghum cultivars for alcohol production
}

\section{F.J.Hills a R.T.Lewellen $\square$ I.O.Skoyen}

\section{Sweet sorghum does well in much of California. Cultivars were tested that showed a potential for produc- ing from 475 to 575 gallons of etha- nol per acre.}

Sweet sorghum has been grown for many years in the southeastern United States in small plantings for making sweet syrup. Plant breeders have developed high-sucrose cultivars to increase the potential of this crop as a sucrose source. This effort has also made sweet sorghum a candidate feed stock for the production of ethanol. Ethanol is added to gasoline to increase the octane rating, reduce pollution, and extend the gasoline supply for internal combustion engines.

The sugars synthesized by sweet sorghum, Sorghum bicolor (L.) Moench., are stored in stems (culms) as is the case with sugarcane. Sugarcane, however, requires 12 to 24 months of tropical climate to mature, whereas sweet sorghum can be grown to maturity in 92 to 180 days. It thus can be grown successfully during the warm season of a temperate climate.

To produce alcohol, the juice must be pressed from the sweet sorghum stems and fermented. The alcohol is then distilled from the fermentation vat. Bagasse, the residual stalk material, can be used as fuel for the distillation process. At maturity, sweet sorghum produces heads (panicles) bearing seeds. The seed crop is relatively small and is of minor importance in furnishing carbohydrate for fermentation or for use as animal feed. For most cultivars, stalk sugar concentration increases from the milk stage to the soft dough stage of the seed, then declines as the seeds become more mature.

Research at the University of California, Davis, has shown that sweet sorghum has characteristics that favor its use for the production of alcohol. It produces about $23 \%$ more fermentable carbohydrate than does field corn, requires only $37 \%$ of the fertilizer nitrogen used by corn, and requires about $17 \%$ less irrigation water.

Another important consideration in growing this crop is the selection of a welladapted cultivar. From 1980 to 1984, the Agricultural Research Service of the U.S. Department of Agriculture sponsored trials throughout the United States to evaluate six cultivars for potential ethanol production. California was one of the test areas with trials at Davis, Brawley, and Salinas. In this report, we present the comparative yields of the six cultivars grown at Davis and Salinas over a 3-year period. Results from a 1980 Rrawley trial are also discussed. Trials at Brawley in 1981 and 1982 were abandoned, because wet and windy conditions caused much lodging and stalk breakage.

\section{Materials and methods}

Five of the six cultivars tested, 'Wray', 'Keller', 'Dale', 'M 81E', and 'Rio', are from U.S. sugar-breeding programs and the other, 'MN 1500', is of African origin. The cultivars were grown each year at each location in a randomized complete block design with four replications. Plots were from 20 to 22 feet in length and three rows wide. Row spacing at Salinas was 56 inches in 1981 and 28 inches in the other two years. At Davis, row spacing was 30 inches. Seeds were planted in April or early May at Davis and in late April to early June at Salinas. Shortly after emergence, seedlings were thinned to 4 or 5 inches between plants within rows.

Harvest was in mid-October at Davis and early December at Salinas. The center row of each three-row plot was harvested at Davis, but all three rows were harvested at Salinas. Stalks were harvested by handcutting at ground level. A 10-plant sample was taken from each plot. The stalks of the sample were stripped of leaves, and the heads removed. The stripped stalks were chopped in small pieces and a subsample of this material was frozen, packed in dry ice, and shipped to the Northern Agricultural Energy Center in Peoria, Illinois, for sugar analysis. 


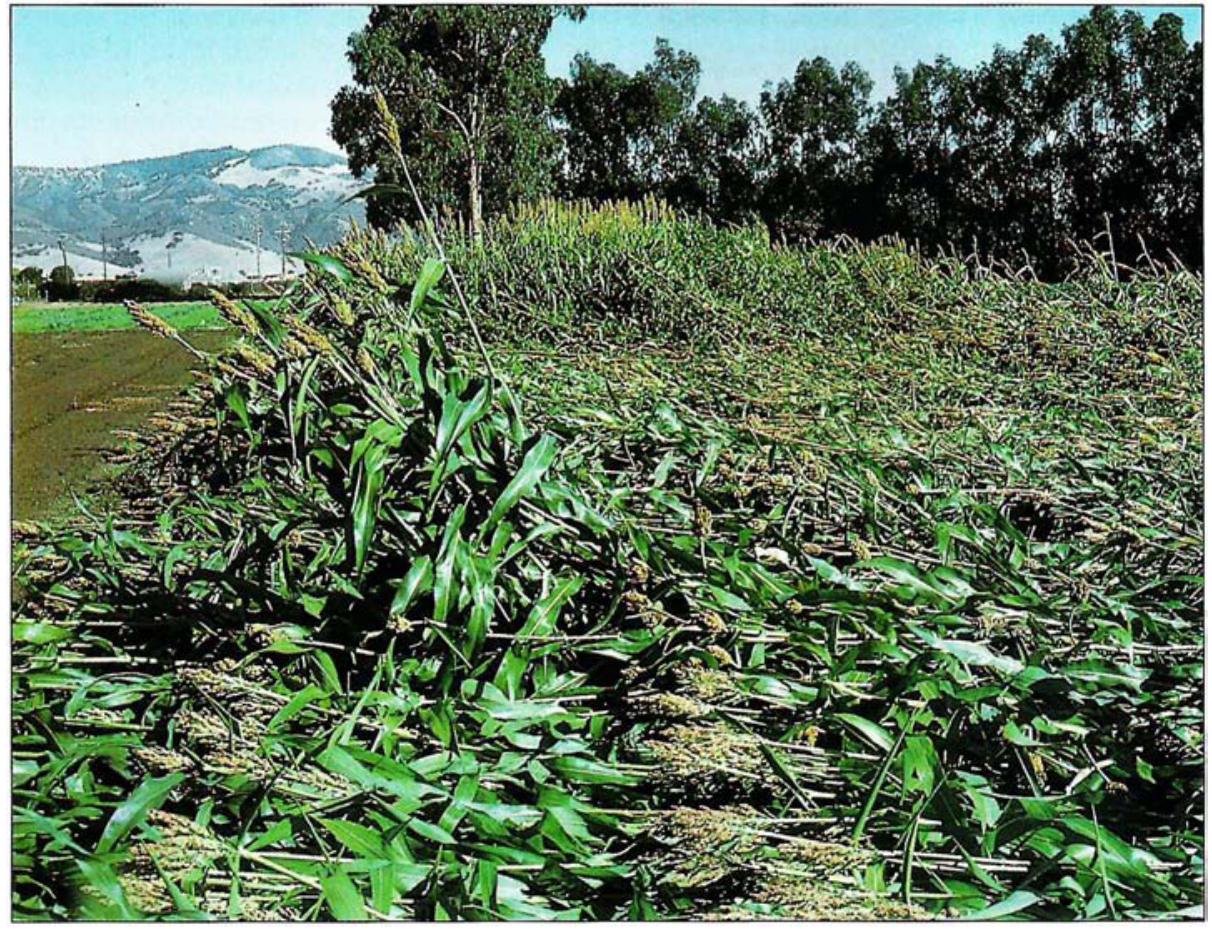

Lodging is a potential problem in growing sweet sorghum. In this trial at Salinas, lodging occurred in November after a rain and wind storm.
Twelve cultivars in a 1980 Brawley test were planted April 30 and harvested November 20. Row spacing was 40 inches, but otherwise experimental methods were similar.

\section{Results and discussion}

All cultivars matured faster at Davis than at Salinas, requiring an average of 119 days to head at Davis compared with 144 days at Salinas. Table 1 summarizes 3-year average production at each location. Total biomass is given by the gross green weight of stalks. Stripped stalks are the portion of the biomass to be crushed to express the stalk juice that contains the sugars for fermentation. Stalk sugar concentration is given on a dry weight basis but can be expressed as a percentage of the fresh weight of stalks by multiplying the dry weight sugar percent by the ratio of the weight of dry stripped stalks to fresh stripped stalks. For example, the average fresh weight stalk concentrations of all sugars at Davis and Salinas were $32.6 \%$ and $40.3 \%$, respectively. The stalk fresh weight sugar concentrations were: $32.6(10.2 / 41.0)=8.1 \%$ and $40.3(7.7 / 29.9)=$ $10.4 \%$. Compared with sugarbeet, a crop extensively grown in California, these are low sugar concentrations. An improvement in sugar concentration of sweet sor-

TABLE 1. Comparison of six sweet sorghum cultivars at two California locations

\begin{tabular}{|c|c|c|c|c|c|c|c|c|c|c|}
\hline \multirow[b]{2}{*}{ Cultivar } & \multirow[b]{2}{*}{$\begin{array}{c}\text { Time from } \\
\text { plant to } \\
\text { head }\end{array}$} & & & \multirow[b]{2}{*}{$\begin{array}{c}\text { Dry wt. } \\
\text { stripped } \\
\text { stalks }\end{array}$} & \multicolumn{4}{|c|}{ Stripped stalk sugar conc. dry wt.basis* } & \multirow[b]{2}{*}{$\begin{array}{l}\text { Hexose } \\
\text { sugar } \\
\text { yield }\end{array}$} & \multirow[b]{2}{*}{$\begin{array}{r}\text { Potentia } \\
\text { ethanol } \\
\text { yield ? }\end{array}$} \\
\hline & & $\begin{array}{r}\text { Gross } \\
\text { stalks }\end{array}$ & $\begin{array}{l}\text { Neight } \\
\text { Stripped } \\
\text { stalks }^{\circ}\end{array}$ & & $\begin{array}{c}\text { Su- } \\
\text { crose }\end{array}$ & $\begin{array}{c}\text { Fruc- } \\
\text { tose }\end{array}$ & $\begin{array}{l}\text { Glu- } \\
\text { cose }\end{array}$ & $\begin{array}{c}\text { Total } \\
\text { hexose } \\
\text { equivalents }\end{array}$ & & \\
\hline & days & $\ldots \ldots \ldots \ldots$ & tons/acre & (................ & .............. & $\ldots \ldots$. & . & $\ldots$ & tons/acre & gal/acre \\
\hline \multicolumn{11}{|l|}{ DAVIS } \\
\hline $\begin{array}{l}\text { Wray } \\
\text { Keller } \\
\text { Dale } \\
\text { M 81E } \\
\text { Rio } \\
\text { MN } 1500\end{array}$ & $\begin{array}{l}138 \\
120 \\
119 \\
125 \\
104 \\
106\end{array}$ & $\begin{array}{l}59.2 \\
50.2 \\
53.2 \\
53.7 \\
42.2 \\
41.1\end{array}$ & $\begin{array}{l}49.5 \\
41.9 \\
42.4 \\
44.4 \\
34.6 \\
33.0\end{array}$ & $\begin{array}{r}12.1 \\
10.8 \\
10.1 \\
10.9 \\
9.2 \\
8.2\end{array}$ & $\begin{array}{l}26.2 \\
22.4 \\
12.0 \\
16.5 \\
26.7 \\
12.5\end{array}$ & $\begin{array}{l}3.6 \\
4.3 \\
9.5 \\
5.4 \\
2.9 \\
5.2\end{array}$ & $\begin{array}{r}5.4 \\
5.7 \\
12.7 \\
8.2 \\
4.1 \\
6.0\end{array}$ & $\begin{array}{l}36.6 \\
33.6 \\
34.8 \\
30.9 \\
35.1 \\
24.3\end{array}$ & $\begin{array}{l}4.32 \\
3.57 \\
3.36 \\
3.34 \\
3.20 \\
1.91\end{array}$ & $\begin{array}{l}576 \\
475 \\
447 \\
445 \\
426 \\
254\end{array}$ \\
\hline $\begin{array}{l}\text { LSD, 5\% } \\
\text { CV, \% } \\
\text { Mean } \\
\text { SE }^{*}\end{array}$ & 119 & $\begin{array}{r}5.8 \\
14.2 \\
49.9 \\
0.8\end{array}$ & $\begin{array}{r}5.3 \\
15.9 \\
41.0 \\
0.8\end{array}$ & $\begin{array}{r}1.5 \\
17.4 \\
10.2 \\
0.2\end{array}$ & $\begin{array}{r}4.7 \\
29.4 \\
19.4 \\
0.7\end{array}$ & $\begin{array}{r}1.5 \\
35.4 \\
5.2 \\
0.2\end{array}$ & $\begin{array}{r}1.9 \\
33.3 \\
7.0 \\
0.3\end{array}$ & $\begin{array}{r}3.5 \\
13.1 \\
32.6 \\
0.5\end{array}$ & $\begin{array}{c}0.64 \\
13.2 \\
3.29 \\
0.09\end{array}$ & $\begin{array}{l}83 \\
23.7 \\
473 \\
12\end{array}$ \\
\hline $\begin{array}{l}\text { SALINAS } \\
\text { Wray } \\
\text { Keller } \\
\text { Dale } \\
\text { M 81E } \\
\text { Rio } \\
\text { MN } 1500\end{array}$ & $\begin{array}{l}189 \\
139 \\
150 \\
141 \\
117 \\
130\end{array}$ & $\begin{array}{r}-41.8 \\
38.5 \\
40.2 \\
39.5 \\
28.0 \\
33.0\end{array}$ & $\begin{array}{l}32.7 \\
32.1 \\
33.6 \\
31.2 \\
23.4 \\
26.5\end{array}$ & $\begin{array}{l}8.3 \\
8.9 \\
8.4 \\
7.5 \\
6.3 \\
6.9\end{array}$ & $\begin{array}{l}26.3 \\
35.9 \\
19.6 \\
24.6 \\
37.6 \\
31.7\end{array}$ & $\begin{array}{r}4.6 \\
1.1 \\
10.8 \\
5.3 \\
0.0 \\
1.5\end{array}$ & $\begin{array}{r}7.1 \\
3.1 \\
11.1 \\
8.2 \\
0.0 \\
3.7\end{array}$ & $\begin{array}{l}39.6 \\
42.0 \\
42.6 \\
39.4 \\
39.5 \\
38.6\end{array}$ & $\begin{array}{l}3.28 \\
3.72 \\
3.59 \\
2.97 \\
2.47 \\
2.67\end{array}$ & $\begin{array}{l}437 \\
495 \\
478 \\
396 \\
327 \\
355\end{array}$ \\
\hline $\begin{array}{l}\text { LSD,5\% } \\
\text { CV,\% } \\
\text { Mean } \\
\text { SE }^{\#}\end{array}$ & 144 & $\begin{array}{r}2.1 \\
7.1 \\
36.8 \\
0.1\end{array}$ & $\begin{array}{r}2.0 \\
8.1 \\
29.9 \\
0.3\end{array}$ & $\begin{array}{l}0.6 \\
9.8 \\
7.7 \\
0.1\end{array}$ & $\begin{array}{r}3.2 \\
10.6 \\
29.3 \\
0.4\end{array}$ & 3.9 & ${ }_{\infty}^{\infty} 5$ & $\begin{array}{l}\text { NS } \\
10.1 \\
40.3 \\
0.6\end{array}$ & $\begin{array}{c}0.31 \\
12.2 \\
3.12 \\
0.05\end{array}$ & $\begin{array}{c}42 \\
12.2 \\
415 \\
6\end{array}$ \\
\hline
\end{tabular}

NOTE: Data are averages of three trials of four replications each for 1981 to 1983.

* On a fresh weight basis, $\%$ sugar $=\%$ sugar dry weight (stripped stalk dry weight/stripped stalk fresh weight).

- Stalks with heads and leaves removed.

$\S$ Hexose equivalent $=1.05$ (\% sucrose $)+\%$ fructose $+\%$ glucose .

"Based on 15.02 pounds hexose/gallon ethanol.

"The $95 \%$ confidence limits for a location mean = mean \pm 2.014 (SE).

** Sugar concentrations are averages for 1981 and 1982 only. No analyses available for 1983

onot computed due to all or nearly all zero values for some cultivars. 
ghum would greatly improve the efficiency of the crop as an ethanol feed stock.

Biomass and stripped stalk yields were considerably higher for the warmer climate of Davis, but the higher stalk sugar concentrations at Salinas made total sugar production and potential ethanol yield similar for both locations. The matured height of the stalks at both locations was about the same (10 to 12 feet), but at Davis, near maximum height was reached by late July and resulted in extensive lodging following an early August furrow irrigation. Slower growth at Salinas enabled the stalks to remain upright until late October or early November. The greater lodging at Davis and the resulting loss of leaf area exposed to sunlight may have had some effect in lowering the sugar content.

There were no interactions between cultivar and year at Davis, indicating that the cultivars performed relatively similarly, one to another, in all 3 years. On average, 'Wray' was superior for potential ethanol yield. There were statistically significant interactions between cultivar and year at Salinas, but in all years, 'Wray' yielded either first or second. At that location, 'Keller', 'Dale', and 'Wray' were the three highest yielding cultivars in terms of potential ethanol yield.

In the 1980 Brawley trial, gross green stalk weight ranged from 26 to 57 tons per acre. The later maturing cultivars, 'MN 1500', 'MER 71-1', and 'MER 60-2', yielded more than 50 tons per acre, whereas the earlier maturing types, 'Wray', 'Ramada', and 'Brawley' were less than 30 tons per acre. Stalk concentration of total soluble solids, estimated from brix readings, ranged from $6.5 \%$ for 'Brandes' to $22.1 \%$ for 'Keller'. The highest estimated ethanol yields were from 'MN 1500', 'Keller', 'MER 71-1', and 'MER 60-2'. Stalk height ranged from less than 7 feet for 'Wray' to 11.5 feet for 'MN 1500'.

From these results, it appears that sweet sorghum would produce well in many areas of the state and that most cultivars used in the southern United States would do well here. However, sweet sorghum is sensitive to day length, and cultivar-by-location interactions for maturity were evident. Additional testing would be required to identify the best cultivar for each major production area and for each harvest period within areas.

F.J. Hills is Extension Agronomist, Emeritus, Department of Agronomy and Range Science, University of California, Davis; $R$. T. Lewellen is Geneticist, and I. O. Skoyen is Agronomist, U.S. Department of Agriculture, Agricultural Research Seroice, Salinas, California. The authors thank Clifford Brown, Superintendent, USDA-ARS, Brawley, for growing the trials there; Gary Peterson, Staff Research Associate, and Akbar Abshahi, graduate student, for help at Davis.

\title{
Clogging of buried drip irrigation systems
}

\author{
Larry J. Schwankl $\square$ Terry L. Prichard
}

\section{Lime precipitate clogging of buried drip irrigation systems is difficult to detect and can cause problems where water quality is poor. Inject- ing a phosphonate was as effective as acid against clogging in two field trials, and may cost less.}

Clogging is one of the most difficult problems facing users of drip irrigation systems. Emitter clogging can seriously interfere with uniform application of irrigation water and system-applied fertilizers. Often, the result is reduced yield and crop quality. Clogging can result from biological growths, physical particulates, or chemical precipitates in the drip system.

Biological growth clogging is most frequently found in drip systems using surface water sources. The standard method of preventing biological growth is a combination of low water $\mathrm{pH}$, chlorine injection, and sand media filtration.

Suspended mineral particles in the water cause physical particulates to clog both groundwater and surface-water-supplied drip systems. Filtration, frequently with screen filters, is used to remove the particulates.

Chemical precipitate clogging is most often encountered in drip systems supplied by groundwater. High levels of calcium, magnesium, bicarbonate, and sulfate can result in chemical precipitation, particularly if the irrigation water is highly alkaline. Calcium carbonate or lime is the most common precipitate. Lowering the $\mathrm{pH}$ to below neutral (7.0) through acid injection has been the standard method of minimizing lime precipitation. In the past, sulfuric acid was added to lower the $\mathrm{pH}$ of the irrigation water, but safety concerns have curtailed its use. Products such as N-pHURIC, which are effective and safer to handle, are more often used today.

Buried drip irrigation systems, in which drip tapes are buried below the ground surface, cause additional problems because clogged orifices cannot be seen. When groundwater is used in these systems, clogging of the small orifices by chemical precipitates can be a serious problem.

Two field experiments were conducted to test an alternative to acid injection for dealing with chemical precipitate clogging in buried drip irrigation systems. This alternative treatment entails injecting into the sys- tem low concentrations of ESI-50, a phosphonate material. This chemical is used as a scale inhibitor in industrial applications but has not been used in agriculture. ESI-50 has Environmental Protection Agency approval for use in potable water. Phosphonates are not persistent in the environment, particularly in the soil.

We selected two field sites for testing. At the first, we monitored a commercial buried drip irrigation system near Ripon, California, which had a history of clogging. The second site was an experimental field at the University of California, Davis.

A bell pepper field near Ripon was chosen because of its history of drip tape clogging, resulting primarily from the quality of the groundwater used for irrigation. The chemical constituents of Ripon irrigation water ( $\mathrm{pH} 7.7)$, in milliequivalents per liter (meq/L), are as follows: calcium, 3.1; magnesium, 0.6; sodium, 1.8; bicarbonate, 3.5; and chlorine, 2.0 .

The peppers were direct-seeded March 23, 1988, into 30 -inch beds treated with herbicide to reduce weed competition. The drip tape (T-Tape) had a wall thickness of 0.014 inch and flow rate of 0.4 gallon per minute per 100 feet of tape at a pressure of 10 psi. The tape was placed at a depth of 4 inches before planting.

There were three treatments at Ripon: (1) continuous injection of ESI-50 for a final irrigation concentration of $4 \mathrm{ppm}$, (2) intermittent injection of ESI-50 for a final concentration of 4 ppm during the last 2 hours of each irrigation, and (3) an untreated control. Four replicates of each treatment were evaluated. Each plot consisted of two 400foot drip tape lines.

Our theory was that the critical time of chemical precipitation was after completion of the irrigation. Factors such as the time irrigation water remains in the drip tubing and increased ionic concentration due to water evaporation can influence precipitate formation. We compared the continuous and intermittent treatments to confirm the hypothesis. The intermittent treatment had the advantage of reduced cost of injected material, but the disadvantage of requiring further automation to control injection times.

The grower chose to add an acid product (N-pHURIC) to the irrigation water to reduce the clogging problems experienced in previous years. Acid injection lowered the $\mathrm{pH}$ of the irrigation water to nearly 6.5. Other liquid fertilizers were added during 